\title{
«Bør Lægeforeningen starte et medisinsk pressebyrå?»
}

\begin{abstract}
Spørsmålet i tittelen ble drøftet i en lederartikkel i Tidsskriftet i 1947 (1947; 67: 21). Bakgrunnen var frustrasjon over medienes dekning av medisinske spørsmål. Lederskribenten trakk frem den danske journalisten Loulou Lassen (1876-1947) som eksempel til etterfølgelse. Ifølge Dansk kvindebiografisk leksikon var Lassen en pioner: «Hidtil havde dette område ikke været et journalistisk felt, idet stoffet, for så vidt det overhovedet fandtes, blev skrevet af læger [...] I begyndelsen blev hun mødt med en udpræget mistro fra de medicinsk fagkyndige, der ikke havde megen tiltro til hendes eller andre lægfolks evne til at forstå de faglige resultater. Men gradvis opnåede hun respekt for sin indsats, også fra medicinsk hold, hvor man efterhånden indså værdien af en professionel popularisering af de videnskabelige resultater og deres relevans for menneskers dagligdag» (1).
\end{abstract}

\section{Litteratur}

1. Dansk kvindebiografisk leksikon. www.kvinfo.dk/side/597/bio/726/origin/170/ (16.4.2010).

\section{Medisinen i dagspressen}

Våre dagblad og den illustrerte presse oversvømmes av mer eller mindre eiendommelige medisinske meddelelser. Snart er det et epokegjørende livs-serum som lanseres, snart er det nye og revolusjonerende midler i behandlingen av kreft eller tuberkulose som er på trappene eller en oppsiktsvekkende metode til å diagnostisere kreft i en enkelt blod-dråpe. [...]

Det later til at den populære presse gjerne vil bringe sine lesere medisinsk stoff. Dette er all ære verd, såfremt det dreier seg om saklig opplysning, men ofte ser det altså ut som det er sensasjon som er den vesentlige side av saken. [...]

Grunnen til kollegenes tilbakeholdenhet er vel frykten for at slike innlegg skal virke som personlig reklame. For øvrig inneholder avisene en del medisinsk stoff utarbeidet av deres egne journalister. I denne kategori finner en intervjuer og referater fra fagpressen, møter og doktordisputaser. Det er imidlertid bare en enkelt avis («Dagbladet») som har journalist som hovedsakelig beskjeftiger seg med medisinske og sosialmedisinske spørsmål.

Ordningen med at dagbladene ansetter faste journalister for medisinske spørsmål har sine store fordeler. Dette system har fungert utmerket i dansk «Politiken» hvor fru Loulou Lassen i mange år har vært fast medisinsk medarbeider, nå avløst av signaturen Erol. Begge disse journalister som tydeligvis har meget gode medisinske kontakter, har til enhver tid brakt leserne verdifull orientering om medisinske spørsmål. 